\title{
The effects of obesity and HER-2 polymorphisms as risk factors for endometrial cancer in Korean women
}

\author{
S-Y Tong, ${ }^{a, *}$ S-Y Ha, ${ }^{b}, *$ K-D Ki, ${ }^{a}$ J-M Lee, ${ }^{a}$ S-K Lee, ${ }^{a}$ K-B Lee, ${ }^{c}$ M-K Kim, ${ }^{d}$ C-H Cho, ${ }^{e}$ S-Y Kwon ${ }^{f}$ \\ ${ }^{a}$ Department of Obstetrics and Gynecology, East-West Neo Medical Center, Kyung Hee University, Seoul, Korea ${ }^{\mathrm{b}}$ Department of Pathology, \\ Gachon University, Gil Medical Center, Inchon, Korea ${ }^{c}$ Department of Obstetrics and Gynecology, Gachon University, Gil Medical Center, \\ Inchon, Korea ${ }^{\mathrm{d}}$ Carcinogenesis Branch, Division of Basic Sciences, National Cancer Center, Goyang-si, Gyeonggi-do, Korea ${ }^{\mathrm{e}}$ Department of \\ Obstetrics and Gynecology, Keimyung University School of Medicine, Daegu, Korea ${ }^{\mathrm{f}}$ Department of Pathology, Keimyung University School \\ of Medicine, Daegu, Korea \\ Correspondence: J-M Lee, MD, PhD, Department of Obstetrics and Gynecology, East-West Neo Medical Center, Kyung Hee University, \#149 \\ Sangil-Dong, Gangdong-Gu, Seoul 134-890, Korea. Email kgo02@hanmail.net
}

Accepted 8 February 2009. Published Online 11 May 2009.

Objective To evaluate the relationship between single nucleotide polymorphisms (SNPs) in the HER-2 gene, body mass index (BMI) and the risk of endometrial cancer.

Design Case-control study.

Setting Medical centres in Korea.

Sample DNA samples and medical histories were obtained from 125 endometrial cancer cases and 302 controls.

Methods The genotypes evaluated in HER-2 at positions -423 , $-655,-776,-857,-1170,-1177,-1253$ of the coding region and two SNPs located in an intron by SNP-IT assay using SNPstream Ultra-high throughput system.

Main outcome measures Odd ratio for endometrial cancer associated with HER-2 polymorphisms and BMI.
Results Cases had a significantly higher BMI than controls and the obese subjects had a 2.65 -fold increased risk for endometrial cancer. However, HER-2 polymorphism was not associated significantly with the risk of endometrial cancer. Subjects with $\mathrm{BMI} \geq 25 \mathrm{~kg} / \mathrm{m}^{2}$ who carried $\mathrm{rs} 1801200 \mathrm{AA}, \mathrm{rs} 1801200 \mathrm{GA} / \mathrm{GG}$, rs1810132 CT/CC, rs2517951 CT/TT and rs1058808 CG/GG genotype had significantly increased risk of endometrial cancer than subjects with a normal BMI ( $P$ for linear trend $<0.05$ ). However, the risk in the subjects with the variant allele for HER-2 genotypes did not differ significantly compared to those with homozygous wild-type allele within specific BMI subgroups.

Conclusions Endometrial cancer risk increased significantly in proportion to BMI. However, HER-2 polymorphism did not affect significantly on the risk of endometrial cancer.

Keywords Body mass index, endometrial neoplasms, HER-2, polymorphism, risk factors, single nucleotide.

Please cite this paper as: Tong S, Ha S, Ki K, Lee J, Lee S, Lee K, Kim M, Cho C, Kwon S. The effects of obesity and HER-2 polymorphisms as risk factors for endometrial cancer in Korean women. BJOG 2009;116:1046-1052.

\section{Introduction}

Endometrial cancer is the most common malignancy of the female genital tract in many developed countries ${ }^{1}$ and has become more prevalent in Korea during the last decade. ${ }^{2}$ There are two different pathogenetic types in endometrial cancer, such as endometrioid and non-endometrioid histological subtype. Of them, endometrioid subtype is estro-

${ }^{*}$ Seo-Yun Tong and Seung-Yeon Ha contributed equally to this work as first authors. gen-dependent and has been known to be associated with obesity, which might cause hyperestrogenism. ${ }^{3}$

The risk of endometrial cancer may be greater in women who have relatives with endometrial cancer $^{4,5}$ and in patients with multiple primary tumours ${ }^{6}$ resulting from conditions such as hereditary nonpolyposis colorectal cancer syndrome. ${ }^{7}$ These studies suggest that genetic factors play a role in the aetiology of the disease and that they may work in concert with environmental risk factors.

HER-2 (also known as erbB-2 or neu), a member of the epidermal growth factor receptor family, is located at 
chromosome 17q21 and encodes a transmembrane glycoprotein (i.e. p185) with tyrosine kinase activity. ${ }^{8-10}$ The HER-2 gene activation was suggested as a risk factor in the development of several cancers. ${ }^{11-13}$ Similarly, the HER-2 protooncogene is thought to increase susceptibility to endometrial cancer. ${ }^{14}$ In addition, HER-2 over-expression is correlated with a poor prognosis in endometrial cancer. ${ }^{15,16}$

A polymorphic change of the HER-2 gene may alter protein tyrosine kinase activity. ${ }^{17}$ Several clinical studies have associated the HER-2 polymorphism with increased risk for breast, prostate and gastric cancer. ${ }^{18-21}$ However, few studies have explored the correlation between HER-2 polymorphisms and the development of endometrial cancer, ${ }^{22,23}$ and the effect of obesity on this correlation.

Thus, we conducted a case-control study to evaluate the hypothesis that HER-2 polymorphisms may affect the risk of endometrial cancer and obesity may modulate these correlation in Korean women.

\section{Materials and methods}

\section{Study subjects}

The study population was identified from tumour registry databases of participating medical centres in Korea from 1998-2006, after obtaining approval from their institutional review board. The study included 125 Korean women who underwent complete surgical staging for histologically confirmed endometrioid adenocarcinoma. The control group consisted of 302 Korean women with benign gynaecologic disease, such as myoma uteri or benign ovarian tumour, who underwent hysterectomy at the same hospital during the same period. Medical records were reviewed to determine age, body mass index (BMI) and tumour grade, stage and size. Tumours were staged according to the FIGO stag- ing system. BMI was calculated as body weight divided by the square of the height $\left(\mathrm{kg} / \mathrm{m}^{2}\right)$. In this study, we evaluated the risk of cancer associated with being overweight (BMI, 23.0 to $24.9 \mathrm{~kg} / \mathrm{m}^{2}$ ) or obese $\left(\right.$ BMI $\geq 25 \mathrm{~kg} / \mathrm{m}^{2}$ ), with the BMI level between 18.5 and $22.9 \mathrm{~kg} / \mathrm{m}^{2}$ as a referent group. ${ }^{24}$

To examine the relationship between HER-2 polymorphisms and histological features of cancer, we defined the low-risk group as patients with grade 1 and stage IA-IB tumours, while the high-risk group was composed of the remaining patients.

\section{Single-nucleotide polymorphism (SNP) selection and genotyping of $H E R-2$}

We genotyped nine SNPs of the HER-2 gene, as determined from the National Center for Biotechnology Information database (www.ncbi.nlm.nih.gov/sites/entrez?db=snp\&cmd= search\&term=). Of these, five SNPs were removed because they were either monomorphic or had low allele frequencies $(<10 \%)$. Consequently, four SNPs [i.e. rs1801200 (I655V), rs1810132, rs2517951, rs1058808 (P1170A)] with allele frequencies greater or equal to $10 \%$ were included in the final analysis (Table 1). The observed genotype frequency in the control subjects was in agreement with the Hardy-Weinberg equilibrium $(P>0.05)$.

Genomic DNA was extracted from paraffin-embedded tissue in tumour-free regions of the uterus ${ }^{25,26}$ using a commercially available DNA isolation kit (MagAttract DNA Mini M48 kit; Qiagen, Chatsworth, CA, USA.), according to the manufacturer's protocol.

Genotype identification was performed with the GenomeLab SNPstream (Ultra-high throughput; UHT system ${ }^{27}$ ) system, which uses multiplexed polymerase chain reaction (PCR) in conjunction with tag array single-base extension

Table 1. Single-nucleotide polymorphisms (SNPS) selected for genotyping in 427 Korean women

\begin{tabular}{|c|c|c|c|c|}
\hline $\begin{array}{l}\text { SNP database } \\
\text { rs no. }\end{array}$ & Allele* & Function & $\begin{array}{l}\text { Minor allele } \\
\text { frequency** }\end{array}$ & HWE*** \\
\hline 1801200 & A/G & Coding, nonsynonymous (I655V) & 0.102 & 0.41 \\
\hline 1810132 & $\mathrm{C} / \mathrm{T}$ & Intron & 0.376 & 0.85 \\
\hline 2517951 & $\mathrm{C} / \mathrm{T}$ & Intron & 0.390 & 0.49 \\
\hline 1058808 & $C / G$ & Coding, nonsynonymous (P1170A) & 0.387 & 0.44 \\
\hline 28933369 & $\mathrm{G} / \mathrm{A}$ & Coding, nonsynonymous (G776S) & 0 & - \\
\hline 28933370 & A/G & Coding, nonsynonymous (A857S) & 0 & - \\
\hline 35757908 & $\mathrm{C} / \mathrm{T}$ & Coding, synonymous (S423S) & 0.002 & - \\
\hline 36085723 & $\mathrm{G} / \mathrm{A}$ & Coding, nonsynonymous (V1253M) & 0 & - \\
\hline 4252656 & $\mathrm{G} / \mathrm{A}$ & Coding, synonymous (L1177L) & 0 & - \\
\hline
\end{tabular}

*Major alleles are listed first; minor alleles are listed second.

${ }^{* *}$ Among all controls.

$* * *$ HWE: $P$ values from chi-square test for Hardy-Weinberg equilibrium. 
genotyping (Beckman Coulter, Fullerton, CA, USA). This system and its accompanying SNPstream software have been described by Demomme and Van Oene. ${ }^{28}$ PCR was performed on an ABI Gene Amp 9700 thermal cycler (Applied Biosystems, Foster City, CA, USA) using Taq Gold DNA polymerase. Multiplexed PCR and genotyping were performed in homogeneous reactions and assay results were read by direct two-colour fluorescence on a SNPstream UHT Array Imager. To ensure quality control, genotyping was blinded to case-control status and a 10\% masked, random sample of subjects was repeatedly tested. Results were concordant for all masked duplicated sets. Genotyping data were obtained from 125 cases and 302 controls; results were reviewed and manually confirmed by experienced researchers.

\section{Statistical analysis}

The comparison for age and BMI between cases and controls was performed using the Student's $t$ test. Unconditional logistic regression analysis was conducted to estimate odds ratios (ORs) and their 90\% confidence intervals (CIs) for associations between BMI and endometrial cancer risk. To measure the associations between HER-2 polymorphisms and the risk of endometrial cancer, individuals were grouped according to genotype. Subjects who carried the homozygous wild-type genotype were considered the reference group. Logistic regression was used to estimate the ORs and 95\% CIs after adjustment for age and BMI and to assess whether common polymorphisms of HER-2 are associated with the risk of endometrial cancer. We evaluated whether BMI could modify the risk of endometrial cancer with the lowest BMI $\left(<23 \mathrm{~kg} / \mathrm{m}^{2}\right)$ subjects in each SNPs group as the reference. Test for linear trend across BMI categories were performed using a series of logistic regression analysis. Interactions were tested by using the log likelihood ratio test. In addition, we evaluated whether HER-2 polymorphisms could modify endometrial cancer risk within a specific BMI subgroup to identify a further subjects at a higher risk of endometrial cancer using unconditional logistic regression models with the subjects with homozygous for the common allele as the reference. We also evaluated the association between HER-2 polymorphisms and histopathological features in the subgroup analyses by stage (i.e. IA, IB versus $\geq$ IC), tumour grade (i.e. 1 versus 2,3 ), and tumour size (i.e. $<2 \mathrm{~cm}$ versus $\geq 2 \mathrm{~cm}$ ). All $P$ value of $<0.05$ was considered statistically significant. All analyses were performed using SAS 8.0 software (SAS Institute, Inc., Cary, NC, USA).

\section{Results}

The mean ages for cases and controls were 53.7 and 44.0 years respectively $(P<0.001)$. Cases were more likely than controls to be overweight and mean BMI was higher in cases than in controls $(P<0.001)$ and the subjects with BMI $\geq 25 \mathrm{~kg} / \mathrm{m}^{2}$ had a 2.65-fold increased risk for endometrial cancer compared to those with BMI $<23 \mathrm{~kg} / \mathrm{m}^{2}$ (adjusted OR $=2.65 ; 95 \% \mathrm{CI}, 1.44-4.89$ ) (Table 2).

Table 3 shows the association between HER-2 polymorphisms and the risk of endometrial cancer, as well as the genotype frequencies of HER-2 polymorphisms in the study subjects. There were no significant differences in allele frequencies and genotype distributions of the SNPs between the two groups. When HER-2 polymorphisms were examined individually, it was not significantly associated with the risk of endometrial cancer.

Given that BMI is a major risk factor for endometrial cancer, we examined the effect of BMI on endometrial cancer risk within specific HER-2 genotypes (Table 4). Compared with a normal BMI $\left(<23 \mathrm{~kg} / \mathrm{m}^{2}\right)$ who carried the rs 1801200 AA genotype, those obese (BMI $\geq 25 \mathrm{~kg} / \mathrm{m}^{2}$ ) who carried the rs1801200 AA genotype had a 2.61-fold higher risk of endometrial cancer (adjusted $\mathrm{OR}=2.61$; 95\% CI, 1.27-5.39). Compared with subjects with a normal BMI who carried the rs 1801200 GA or GG genotype,

Table 2. Characteristics of study subjects

\begin{tabular}{|c|c|c|c|}
\hline Variables & $\begin{array}{c}\text { Controls, } \\
n=302(\%)\end{array}$ & $\begin{array}{c}\text { Cases, } \\
n=125(\%)\end{array}$ & $P$ value \\
\hline \multicolumn{4}{|l|}{ Age (years) } \\
\hline $\begin{array}{l}\text { Mean } \pm \text { SD } \\
\text { (range) }\end{array}$ & $\begin{array}{c}44.0 \pm 5.35 \\
(26-64)\end{array}$ & $\begin{array}{c}53.7 \pm 11.5 \\
(29-81)\end{array}$ & $<0.001$ \\
\hline \multicolumn{4}{|c|}{$B M I *(\%)\left(k g / m^{2}\right)$} \\
\hline$<23$ & $118(39.1)$ & $30(24.0)$ & 1.0 (ref.)** \\
\hline $23-25$ & $103(34.1)$ & $34(27.2)$ & $1.19(0.62-2.29)^{* * *}$ \\
\hline$\geq 25$ & $81(26.8)$ & $61(48.8)$ & $2.65(1.44-4.89)^{\star * *}$ \\
\hline $\begin{array}{l}\text { Mean } \pm \text { SD } \\
\text { (range) }\end{array}$ & $\begin{array}{l}23.7 \pm 2.20 \\
(18.2-34.1)\end{array}$ & $\begin{array}{l}25.4 \pm 3.58 \\
(19.5-49.9)\end{array}$ & $<0.001$ \\
\hline \multicolumn{4}{|l|}{ Stage } \\
\hline IA & - & $24(19)$ & \\
\hline IB & - & $54(43)$ & \\
\hline IC & - & $22(18)$ & \\
\hline$\|$ & - & $15(12)$ & \\
\hline III & - & $10(8)$ & \\
\hline \multicolumn{4}{|l|}{ Grade } \\
\hline 1 & - & $85(68)$ & \\
\hline 2 & - & $30(24)$ & \\
\hline 3 & - & $10(8)$ & \\
\hline \multicolumn{4}{|l|}{ Tumour size } \\
\hline$<2 \mathrm{~cm}$ & - & $17(18)$ & \\
\hline$\geq 2 \mathrm{~cm}$ & - & $78(82)$ & \\
\hline $\begin{array}{l}\text { *BMI, body } \\
\text { **Reference } \\
\text { ***Age-adju } \\
\text { unconditiona }\end{array}$ & $\begin{array}{l}\text { lass index. } \\
\text { category. } \\
\text { sted odds rat } \\
\text { logistic regressi }\end{array}$ & $(95 \% \quad \mathrm{Cl})$ & was calculated via \\
\hline
\end{tabular}


Table 3. Association between HER-2 polymorphisms and the risk of endometrial cancer

\begin{tabular}{|c|c|c|c|c|}
\hline \multirow[t]{2}{*}{ SNP } & \multirow[t]{2}{*}{ Genotype } & \multirow{2}{*}{$\frac{\text { Controls }}{N(\%)}$} & \multirow{2}{*}{$\frac{\text { Cases }}{N(\%)}$} & \multirow[t]{2}{*}{ OR $(95 \% \mathrm{Cl}) *$} \\
\hline & & & & \\
\hline \multirow[t]{3}{*}{ rs1801200 } & AA & $241(81)$ & $90(80)$ & 1 (ref.) \\
\hline & GA & 53 (18) & $23(20)$ & $1.13(0.59-2.16)$ \\
\hline & GG & $4(1)$ & $0(0)$ & - \\
\hline \multirow[t]{3}{*}{ rs1810132 } & $C C$ & $118(39)$ & $47(41)$ & 1 (ref.) \\
\hline & $C T$ & $134(45)$ & $55(47)$ & $1.41(0.82-2.42)$ \\
\hline & $\mathrm{TT}$ & $48(16)$ & $14(12)$ & $0.97(0.44-2.14)$ \\
\hline \multirow[t]{3}{*}{ rs2517951 } & $C C$ & $118(39)$ & $47(39)$ & 1 (ref.) \\
\hline & $C T$ & $132(44)$ & $53(44)$ & $1.32(0.76-2.29)$ \\
\hline & $\mathrm{TT}$ & 51 (17) & $20(17)$ & $1.40(0.68-2.88)$ \\
\hline \multirow[t]{3}{*}{ rs1058808 } & $C C$ & $117(39)$ & $49(40)$ & 1 (ref.) \\
\hline & CG & $135(45)$ & $54(44)$ & $1.16(0.67-2.00)$ \\
\hline & GG & $49(16)$ & $19(16)$ & $1.39(0.68-2.87)$ \\
\hline
\end{tabular}

*ORs and $95 \% \mathrm{Cls}$ were calculated via unconditional logistic regression, adjusted for age and body mass index.

subjects with BMI $\geq 25 \mathrm{~kg} / \mathrm{m}^{2}$ who carried the $\mathrm{rs} 1801200$ GA or GG genotype also had a increased risk of endometrial cancer (adjusted OR $=4.46 ; 95 \%$ CI, 0.98-20.17). Thus, the risk of endometrial cancer was found to increase significantly in proportion to BMI in the subjects with rs1801200 AA ( $P$ for linear trend $=0.008)$ or $\mathrm{GA} / \mathrm{GG}$
( $P$ for linear trend $=0.033$ ) genotype and the interaction between BMI and HER-2 genotypes in regard to the risk of endometrial cancer was significant $(P$ for interaction $<0.05)$. However, some different findings were observed for other SNPs. For women with the variant allele for rs1810132, rs2517951 and rs1058808 genotypes, the subjects with $B M I \geq 25 \mathrm{~kg} / \mathrm{m}^{2}$ had a significantly increased risk of endometrial cancer compared to subjects with a normal BMI ( $P$ for linear trend $<0.05$ ). However, the effect of BMI in regard to the risk of endometrial cancer was not statistically significant in the subjects with homozygous wild-type allele for rs1810132, rs2517951 and rs1058808 genotypes ( $P$ for linear trend $>0.05$ ). Then, we compared endometrial cancer risk in the subjects with homozygous wild-type or variant allelic genotype to assess the effect of HER-2 SNPs in regard to endometrial cancer risk within specific BMI subgroups to identify a further subjects at a higher risk of endometrial cancer (Table 5). The risk of endometrial cancer in the subjects with the variant allele for HER-2 genotypes did not differ significantly compared to those with homozygous wild-type allele.

We also evaluated whether HER-2 polymorphisms influence histopathological characteristics of endometrial cancer, such as grade, stage and tumour size. HER-2 polymorphisms were not significantly associated with the risk of advanced stage, poorly differentiated tumours and large tumour size (Table 6).

Table 4. Association of body mass index and endometrial cancer risk within specific HER-2 genotypes

\begin{tabular}{|c|c|c|c|c|c|c|c|}
\hline & & & $\mathrm{BMI}^{*}<23$ & $23 \leq \mathrm{BMI}^{*}<25$ & $\mathrm{BMI}^{*} \geq 25$ & $\begin{array}{c}P \text { for } \\
\text { linear trend }\end{array}$ & $\begin{array}{c}\text { Interaction } \\
\boldsymbol{P} \text {-value }\end{array}$ \\
\hline \multirow[t]{4}{*}{ rs1801200 } & AA & $N$ (control/case) & $(94 / 20)$ & $(81 / 23)$ & $(63 / 38)$ & & \\
\hline & & OR $(95 \% \mathrm{Cl})^{* *}$ & $1 * * *$ & $1.24(0.58-2.67)$ & $2.61(1.27-5.39)$ & 0.008 & 0.019 \\
\hline & GAVGG & $N$ (control/case) & $(20 / 3)$ & $(21 / 4)$ & $(15 / 15)$ & & \\
\hline & & OR $(95 \% \mathrm{Cl})^{* *}$ & $1 * * *$ & $0.96(0.16-5.71)$ & $4.46(0.98-20.17)$ & 0.033 & 0.049 \\
\hline \multirow[t]{4}{*}{ rs1810132 } & CC & $N$ (control/case) & $(44 / 11)$ & $(41 / 16)$ & $(32 / 19)$ & & \\
\hline & & OR $(95 \% \mathrm{Cl})^{\star \star}$ & $1 * * *$ & $1.45(0.50-4.22)$ & $2.83(0.98-8.19)$ & 0.052 & 0.138 \\
\hline & $\mathrm{CT} / \mathrm{TT}$ & $N$ (control/case) & $(71 / 13)$ & $(62 / 14)$ & $(46 / 36)$ & & \\
\hline & & OR $(95 \% \mathrm{Cl}) * *$ & $1 * * *$ & $1.13(0.47-2.69)$ & $2.99(1.37-6.56)$ & 0.005 & 0.008 \\
\hline \multirow[t]{4}{*}{ rs2517951 } & $\mathrm{CC}$ & $N$ (control/case) & $(44 / 13)$ & $(41 / 16)$ & $(32 / 16)$ & & \\
\hline & & OR $(95 \% \mathrm{Cl})^{\star *}$ & $1 * * *$ & $1.18(0.41-3.35)$ & $2.09(0.72-6.08)$ & 0.175 & 0.351 \\
\hline & $\mathrm{CT} / \mathrm{TT}$ & $N$ (control/case) & $(72 / 13)$ & $(62 / 15)$ & $(47 / 37)$ & & \\
\hline & & OR $(95 \% \mathrm{Cl})^{* *}$ & $1 * * *$ & $1.24(0.52-2.92)$ & $2.96(1.35-6.47)$ & 0.005 & 0.011 \\
\hline \multirow[t]{4}{*}{ rs1058808 } & CC & $N$ (control/case) & $(44 / 14)$ & $(40 / 16)$ & $(32 / 17)$ & & \\
\hline & & OR $(95 \% \mathrm{Cl})^{* *}$ & $1 * * *$ & $1.34(0.48-3.72)$ & $2.27(0.8-6.43)$ & 0.123 & 0.288 \\
\hline & CG/GG & $N$ (control/case) & $(72 / 13)$ & $(63 / 15)$ & $(47 / 37)$ & & \\
\hline & & OR $(95 \% \mathrm{Cl})^{\star *}$ & $1 * * *$ & $1.12(0.47-2.67)$ & $2.91(1.33-6.37)$ & 0.006 & 0.009 \\
\hline
\end{tabular}


Table 5. Association of HER-2 gynotypes and endometrial cancer risk within specific body mass index subgroups

\begin{tabular}{|c|c|c|c|c|c|c|c|}
\hline \multirow{2}{*}{ rs1801200 } & & \multicolumn{2}{|c|}{$\mathrm{BMI}^{*}<23$} & \multicolumn{2}{|c|}{$23 \leq$ BMI* $^{*}<25$} & \multicolumn{2}{|c|}{ BMI* $^{2} 25$} \\
\hline & & $A A$ & GA/GG & $A A$ & GA/GG & $\mathrm{AA}$ & GA/GG \\
\hline & $N$ (control/case) & $(94 / 20)$ & $(20 / 3)$ & $81 / 23$ & $(21 / 4)$ & $(63 / 38)$ & $(15 / 15)$ \\
\hline & $\mathrm{OR}(95 \% \mathrm{Cl})^{* *}$ & $1 * * *$ & $0.92(0.23-3.63)$ & $1 * * *$ & $0.73(0.18-2.91)$ & $1 * * *$ & $1.60(0.63-4.07)$ \\
\hline & $P$ value & & 0.9015 & & 0.6526 & & 0.3285 \\
\hline \multirow[t]{4}{*}{ rs1810132 } & & $\mathrm{CC}$ & $\mathrm{CT} / \mathrm{TT}$ & $\mathrm{CC}$ & $\mathrm{CT} / \mathrm{TT}$ & CC & $\mathrm{CT} / \mathrm{TT}$ \\
\hline & $N$ (control/case) & $(44 / 11)$ & $(71 / 13)$ & $(41 / 16)$ & $(62 / 14)$ & $(32 / 19)$ & $(46 / 36)$ \\
\hline & $\mathrm{OR}(95 \% \mathrm{Cl})^{* *}$ & $1 * \star *$ & $1.12(0.42-2.99)$ & $1 * * *$ & $1.01(0.39-2.66)$ & $1 * * *$ & $1.32(0.58-3.01)$ \\
\hline & $P$ value & & 0.8286 & & 0.9799 & & 0.5065 \\
\hline \multirow[t]{4}{*}{ rs2517951 } & & $C C$ & $\mathrm{CT} / \mathrm{TT}$ & $\mathrm{CC}$ & $\mathrm{CT} / \mathrm{TT}$ & $\mathrm{CC}$ & $\mathrm{CT} / \mathrm{TT}$ \\
\hline & $N$ (control/case) & $(44 / 13)$ & $(72 / 13)$ & $(41 / 16)$ & $(62 / 15)$ & $(32 / 16)$ & $(47 / 37)$ \\
\hline & $\mathrm{OR}(95 \% \mathrm{Cl})^{* *}$ & $1 * * *$ & $0.98(0.37-2.56)$ & $1 * * *$ & $1.21(0.46-3.20)$ & $1 * * *$ & $1.52(0.65-3.56)$ \\
\hline & $P$ value & & 0.9653 & & 0.7028 & & 0.3353 \\
\hline \multirow[t]{4}{*}{ rs1058808 } & & CC & $\mathrm{CG} / \mathrm{GG}$ & CC & $\mathrm{CG} / \mathrm{GG}$ & CC & $\mathrm{CG} / \mathrm{GG}$ \\
\hline & $N$ (control/case) & $(44 / 14)$ & $(72 / 13)$ & $(40 / 16)$ & $(63 / 15)$ & $(32 / 17)$ & $(47 / 37)$ \\
\hline & $\mathrm{OR}(95 \% \mathrm{Cl})^{* *}$ & $1 * * *$ & $0.99(0.38-2.58)$ & $1 * * *$ & $0.94(0.36-2.45)$ & $1 * * *$ & $1.39(0.60-3.21)$ \\
\hline & $P$ value & & 0.9782 & & 0.8990 & & 0.4417 \\
\hline
\end{tabular}

Table 6. Association between HER-2 genotype and histopathological features of endometrioid endometrial cancer

\begin{tabular}{|c|c|c|c|c|c|c|c|c|c|}
\hline & & \multicolumn{2}{|c|}{ rs1801200 } & \multicolumn{2}{|c|}{ rs1810132 } & \multicolumn{2}{|c|}{ rs2517951 } & \multicolumn{2}{|c|}{ rs1058808 } \\
\hline & & AA & GA/GG & CC & $\mathrm{CT} / \mathrm{TT}$ & CC & $\mathrm{CT} / \mathrm{TT}$ & CC & CG/GG \\
\hline $\begin{array}{l}\text { Control(normal) } \\
\text { Stage }\end{array}$ & $N(\%)$ & $241(81)$ & $57(19)$ & 118 (39) & $182(61)$ & 118 (39) & $183(61)$ & 117 (39) & $184(61)$ \\
\hline $\mathrm{IA}$ and $\mathrm{IB}$ & $N(\%)$ & $56(81)$ & $13(19)$ & $29(41)$ & $42(59)$ & $31(41)$ & $44(59)$ & $32(42)$ & $45(58)$ \\
\hline & OR $(95 \% \mathrm{Cl})^{*}$ & $1.00 * *$ & $1.22(0.55-2.69)$ & $1.00 * *$ & $1.03(0.55-1.92)$ & $1.00 * *$ & $1.04(0.56-1.94)$ & $1.00 * *$ & $1.05(0.57-1.96)$ \\
\hline$\geq I C$ & $\begin{array}{l}N(\%) \\
\text { OR }(95 \% \mathrm{Cl})^{*}\end{array}$ & $\begin{array}{l}34(77) \\
1.00 * *\end{array}$ & $\begin{array}{l}10(23) \\
1.18(0.45-3.13)\end{array}$ & $\begin{array}{l}18(40) \\
1.00^{\star *}\end{array}$ & $\begin{array}{l}27(60) \\
1.35(0.60-3.03)\end{array}$ & $\begin{array}{l}16(36) \\
1.00 * *\end{array}$ & $\begin{array}{l}29(64) \\
1.51(0.66-3.45)\end{array}$ & $\begin{array}{l}17(38) \\
1.00 * *\end{array}$ & $\begin{array}{l}28(62) \\
1.13(0.51-2.49)\end{array}$ \\
\hline Grade & & & & & & & & & \\
\hline 1 & $\begin{array}{l}N(\%) \\
\text { OR }(95 \% \mathrm{Cl})^{*}\end{array}$ & $\begin{array}{l}60(80) \\
1.00 \text { ** }\end{array}$ & $\begin{array}{c}15(20) \\
0.92(0.44-1.92)\end{array}$ & $\begin{array}{l}33(41) \\
1.00^{* *}\end{array}$ & $\begin{array}{l}47(59) \\
1.12(0.63-1.97)\end{array}$ & $\begin{array}{l}32(39) \\
1.00 * *\end{array}$ & $\begin{array}{l}50(61) \\
1.23(0.70-2.18)\end{array}$ & $\begin{array}{l}34(40) \\
1.00^{* *}\end{array}$ & $\begin{array}{l}49(60) \\
1.09(0.62-1.91)\end{array}$ \\
\hline 2 and 3 & $\begin{array}{l}N(\%) \\
\text { OR }(95 \% \mathrm{Cl})^{*}\end{array}$ & $\begin{array}{l}30(79) \\
1.00 \text { ** }\end{array}$ & $\begin{array}{c}8(21) \\
1.75(0.59-5.18)\end{array}$ & $\begin{array}{l}14(39) \\
1.00 * *\end{array}$ & $\begin{array}{l}22(61) \\
1,73(0.66-4.57)\end{array}$ & $\begin{array}{l}15(39) \\
1.00 * *\end{array}$ & $\begin{array}{l}23(61) \\
1.67(0.64-4.40)\end{array}$ & $\begin{array}{l}15(38) \\
1.00 * *\end{array}$ & $\begin{array}{c}24(62) \\
1.66(0.63-4.35)\end{array}$ \\
\hline Tumour size & & & & & & & & & \\
\hline$<2 \mathrm{~cm}$ & $\begin{array}{l}N(\%) \\
\text { OR }(95 \% \mathrm{Cl})^{*}\end{array}$ & $\begin{array}{l}17(81) \\
1.00 * *\end{array}$ & $\begin{array}{c}4(19) \\
1.18(0.34-4.10)\end{array}$ & $\begin{array}{l}11(46) \\
1.00 * \star\end{array}$ & $\begin{array}{l}13(54) \\
1.06(0.43-2.66)\end{array}$ & $\begin{array}{l}12(48) \\
1.00 * *\end{array}$ & $\begin{array}{c}13(52) \\
0.96(0.39-2.36)\end{array}$ & $\begin{array}{l}12(48) \\
1.00 * *\end{array}$ & $\begin{array}{c}13(52) \\
0.95(0.39-2.34)\end{array}$ \\
\hline$\geq 2 \mathrm{~cm}$ & $\begin{array}{l}N(\%) \\
\text { OR }(95 \% \mathrm{Cl})^{*}\end{array}$ & $\begin{array}{l}50(78) \\
1.00 * *\end{array}$ & $\begin{array}{c}14(22) \\
1.22(0.55-2.69)\end{array}$ & $\begin{array}{l}26(39) \\
1.00 * *\end{array}$ & $\begin{array}{l}40(61) \\
1.16(0.60-2.25)\end{array}$ & $\begin{array}{l}25(37) \\
1.00 * *\end{array}$ & $\begin{array}{c}42(63) \\
1.24(0.64-2.42)\end{array}$ & $\begin{array}{l}27(40) \\
1.00 * *\end{array}$ & $\begin{array}{l}41(60) \\
1.05(0.55-2.02)\end{array}$ \\
\hline
\end{tabular}

*ORs and $95 \% \mathrm{Cls}$ were calculated via unconditional logistic regression, adjusted for age and body mass index.

$\star \star$ Reference category.

\section{Discussion}

HER-2 proto-oncogene has been suggested as an important risk factor in several cancers including endometrial cancer. ${ }^{11-14}$ In addition, HER-2 polymorphism has been reported to be associated with an increased risk of breast, prostate and gastric cancer. ${ }^{18-21}$ The present case-control study examined common SNPs in the HER-2 gene and showed a lack of evidence of association between HER-2 polymorphisms and the risk of endometrioid endometrial 
cancer. Furthermore, there was a lack of association between HER-2 polymorphisms and the histopathological features of endometrioid endometrial cancer. Only few studies have examined the correlation between HER-2 polymorphisms and the development of endometrial cancer. $^{22,23}$ These studies, conducted in Japanese ${ }^{22}$ and Swedish $^{23}$ populations, also found that HER-2 polymorphisms are not associated with endometrial cancer.

The present study, however, showed the significant association between obesity (BMI $\geq 25 \mathrm{~kg} / \mathrm{m}^{2}$ ) and endometrioid endometrial cancer risk using logistic regression analysis model. This finding is consistent with the results of several epidemiologic studies that obesity is an important risk factor for endometrial cancer. ${ }^{29,30}$ Women who weigh 9-22 kg more than their ideal body weight have a three-fold increased risk and women who weigh more than $22 \mathrm{~kg}$ above their ideal body weight have a nine-fold increased risk of developing endometrial cancer when compared with matched controls of women at their ideal body weight, because extraovarian estrogen, derived from androgens aromatised in adipose tissue, plays an important role in the development of endometrial cancer. ${ }^{31}$

To our knowledge, the joint association between HER-2 polymorphism and obesity in regard to the risk of endometrial cancer has not been assessed. In the present study, using lean (i.e. BMI $<23 \mathrm{~kg} / \mathrm{m}^{2}$ ) variant type allele carriers for rs1810132, rs2517951 and rs1058808 as references, we found that obese (i.e. BMI $\geq 25 \mathrm{~kg} / \mathrm{m}^{2}$ ) variant allele carriers had approximately three-fold significantly increased risk of endometrial cancer, whereas their obese wild-type counterparts had no statistically significant increased risk. At the first glance, our findings seem to suggest that obese carriers with minor variant allele of the HER-2 polymorphism may have an increased risk of endometrial cancer than nonobese carriers with variant type allele and may be consistent with that the HER-2 I655V minor allele variant may be functionally important. ${ }^{18}$ However, the risk of endometrial cancer in the subjects with the variant allele for HER-2 genotypes did not differ significantly compared to those with homozygous wild-type allele within specific BMI subgroups. Thus, the effect of HER-2 polymorphism on the risk of endometrial cancer was not significant, even in combining with BMI.

As the mechanism of HER-2 gene amplification has not yet been identified, it remains unclear whether genetic polymorphisms may act in concert with epidemiologic factor such as obesity to affect amplification of this gene. ${ }^{18}$

The present study is limited by the relatively small sample size. However, this is the first study to describe the association between HER-2 polymorphisms and epidemiologic factor such as BMI on the risk of endometrial cancer. Although the present study may provide informative and supportive data relating to the clinical significance of obesity and genetic polymorphism in endometrial cancer, future large studies should explore this putative gene-epidemiology interaction to explain the development of endometrioid endometrial cancer.

\section{Disclosure of interests}

The authors declare that there are no conflicts of interest.

\section{Contribution to authorship}

Each author has participated actively and sufficiently in this study. L.J.M., T.S.Y. and H. S.Y. were the main contributors to the conception, design and preparation of manuscripts. K.K.D., L.K.B., L.S.K., C.C.H. and K.S.Y. have contributed materials and data management. Kim MK was responsible for verification of the statistical calculations. L.J.M. supervised the project and edited the manuscripts to produce the final draft. Each author revised critically the manuscript and provided final approval of the version to be published.

\section{Details of ethics approval}

Ethics approval was obtained from the institutional committee of East-West Neo medical centre. (Ref No KHNMC IRB 2007-003).

\section{Funding}

This study was supported by the Korean Government (MOEHRD, Basic Research Promotion Fund, KRF2007- I00458-E00287).

\section{Acknowledgements}

This study was supported by a grant from the Korean Research Foundation, funded by the Korean Government (MOEHRD, Basic Research Promotion Fund, KRF2007- I00458-E00287).

\section{References}

1 Parkin DM, Pisani P, Ferlay J. Estimates of the worldwide incidence of 25 major cancers in 1990. Int J Cancer 1999;80:827-41.

2 SOG Gynecologic Oncology Committee. Annual Report of Gynecologic Cancer Registry Program in Korea for 2004 (Jan. 1st, 2004Dec. 31st, 2004). Korean J Obstet Gynecol 2007;50:28-78.

3 Henderson BE, Feigelson HS. Hormonal carcinogenesis. Carcinogenesis 2000;21:427-33.

4 Parazzini F, La Vecchia C, Moroni S, Chatenoud L, Ricci E. Family history and the risk of endometrial cancer. Int J Cancer 1994;59:460-2.

5 Sandles LG, Shulman LP, Elias S, Photopulos GJ, Smiley LM, Posten WM, et al. Endometrial adenocarcinoma: genetic analysis suggesting heritable site-specific uterine cancer. Gynecol Oncol 1992;47:16771.

6 Schwartz Z, Ohel G, Birkenfeld A, Anteby SO, Schenker JG. Second primary malignancy in endometrial carcinoma patients. Gynecol Oncol 1985;22:40-5. 
7 Lynch HT, Lanspa S, Smyrk T, Boman B, Watson P, Lynch J. Hereditary nonpolyposis colorectal cancer (Lynch syndromes I \& II). Genetics, pathology, natural history, and cancer control, Part I. Cancer Genet Cytogenet 1991;53:143-60.

8 Semba K, Kamata N, Toyoshima K, Yamamoto T. A v-erbB-related protooncogene, c-erbB-2, is distinct from the c-erbB-1/epidermal growth factor-receptor gene and is amplified in a human salivary gland adenocarcinoma. Proc Natl Acad Sci USA 1985;82:6497-501.

9 Yamamoto T, Ikawa S, Akiyama T, Semba K, Nomura N, Miyajima $\mathrm{N}$, et al. Similarity of protein encoded by the human c-erb-B-2 gene to epidermal growth factor receptor. Nature 1986;319:230-4.

10 Di Fiore PP, Pierce JH, Kraus MH, Segatto O, King CR, Aaronson SA. erbB-2 is a potent oncogene when overexpressed in NIH/3T3 cells. Science 1987;237:178-82.

11 Slamon DJ, Godolphin W, Jones LA, Holt JA, Wong SG, Keith DE, et al. Studies of the HER-2/neu proto-oncogene in human breast and ovarian cancer. Science 1989;244:707-12.

12 Jardines L, Weiss M, Fowble B, Greene M. neu(c-erbB-2/HER2) and the epidermal growth factor receptor (EGFR) in breast cancer. Pathobiology 1993;61:268-82.

13 Hynes NE, Stern DF. The biology of erbB-2/neu/HER-2 and its role in cancer. Biochim Biophys Acta 1994;1198:165-84.

14 Rolitsky CD, Theil KS, McGaughy VR, Copeland LJ, Niemann TH. HER-2/neu amplification and overexpression in endometrial carcinoma. Int J Gynecol Pathol 1999;18:138-43.

15 Busse D, Doughty RS, Arteaga CL. HER-2/neu (erbB-2) and the cell cycle. Semin Oncol 2000;27:3-8; discussion 92-100.

16 Anderson NG, Ahmad T. ErbB receptor tyrosine kinase inhibitors as therapeutic agents. Front Biosci 2002;7:d1926-40.

17 Fleishman SJ, Schlessinger J, Ben-Tal N. A putative molecularactivation switch in the transmembrane domain of erbB2. Proc Natl Acad Sci USA 2002;99:15937-40.

18 Xie D, Shu XO, Deng Z, Wen WQ, Creek KE, Dai Q, et al. Population-based, case-control study of HER2 genetic polymorphism and breast cancer risk. J Natl Cancer Inst 2000;92:412-7.

19 Montgomery KG, Gertig DM, Baxter SW, Milne RL, Dite GS, McCredie MR, et al. The HER2 I655V polymorphism and risk of breast cancer in women <age 40 years. Cancer Epidemiol Biomarkers Prev 2003;12:1109-11.

20 Benusiglio PR, Lesueur F, Luccarini C, Conroy DM, Shah M, Easton DF, et al. Common ERBB2 polymorphisms and risk of breast cancer in a white British population: a case-control study. Breast Cancer Res 2005;7:R204-9.

21 McKean-Cowdin R, Kolonel LN, Press MF, Pike MC, Henderson BE. Germ-line HER-2 variant and breast cancer risk by stage of disease. Cancer Res 2001;61:8393-4.

22 Kitao K, Yoshida S, Kennedy S, Takemura N, Sugimoto M, Deguchi $\mathrm{M}$, et al. Epidermal growth factor receptor and human epidermal growth factor receptor 2 gene polymorphisms in endometrial cancer in a Japanese population. Reprod Sci 2007;14:349-57.

23 Einarsdottir K, Humphreys K, Bonnard C, Li Y, Li Y, Chia KS, et al. Effect of ATM, CHEK2 and ERBB2 TAGSNPs and haplotypes on endometrial cancer risk. Hum Mol Genet 2007;16:154-64.

24 World Health Organization, International Association for the Study of Obesity, International Obesity Task Force. The Asia-Pacific Perspective: Redefining Obesity and its Treatment. Caulfield, VIC, Australia: International Diabetes Institute, 2000.

25 Miller SA, Dykes DD, Polesky HF. A simple salting out procedure for extracting DNA from human nucleated cells. Nucleic Acids Res 1988; 16:1215.

26 Thyagarajan B, Anderson KE, Kong F, Selk FR, Lynch CF, Gross MD. New approaches for genotyping paraffin wax embedded breast tissue from patients with cancer: the lowa women's health study. J Clin Pathol 2005;58:955-61.

27 Bell PA, Chaturvedi S, Gelfand CA, Huang CY, Kochersperger M, Kopla R, et al. SNPstream UHT: ultra-high throughput SNP genotyping for pharmacogenomics and drug discovery. BioTechniques 2002; Suppl:70-72, 74, 76-77.

28 Denomme GA, Van Oene M. High-throughput multiplex singlenucleotide polymorphism analysis for red cell and platelet antigen genotypes. Transfusion 2005;45:660-6.

29 Furberg AS, Thune I. Metabolic abnormalities (hypertension, hyperglycemia and overweight), lifestyle (high energy intake and physical inactivity) and endometrial cancer risk in a Norwegian cohort. Int $J$ Cancer 2003;104:669-76.

30 Goodman MT, Hankin JH, Wilkens LR, Lyu LC, McDuffie K, Liu LQ, et al. Diet, body size, physical activity, and the risk of endometrial cancer. Cancer Res 1997;57:5077-85.

31 Parazzini F, La Vecchia C, Bocciolone L, Franceschi S. The epidemiology of endometrial cancer. Gynecol Oncol 1991;41:1-16. 